Litteratur

1. Bjørnsen LP, Uleberg O. Akuttmottaket trenger egne spesialister. Tidsskr Nor Legeforen 2015: 135: 1230-2.

2. Eusim curriculum www.eusem.org/cms/assets/1/pdf/ european_curriculum_for_em-aug09-djw.pdf (23.10.2015).

3. Norsk standard for anestesi. Tilgjengelig på http://nafweb.no/dokumenter/ ? $\mathrm{cp}=2$ (23.10.2015)

4. Faglige konsekvenser av alternativer for sykehusstruktur. https://www.regjeringen.no/contentassets/9ba3489d35794be7a41cea2cf02af85d/ rapport_sykehusstruktur_ekspertgruppe_040515.pdf (23.10.2015).

5. Nordseth T, Skogvoll E, Gisvold SE. Anestesiologisk akutthjelp i sykehus. Tidsskr Nor Lægeforen 2005; 125: 3124-6.

\section{Re: Et ulogisk og uheldig bivirkningsbegrep}

«En utvidet definisjon av bivirkningsbegrepet og et økt antall meldinger kan i verste fall vanskeliggjøre arbeidet for at legemiddelbehandling skal bli sikrere», skriver Slørdal og Christoffersen i en artikkel i Tidsskriftet (1). Det virker ulogisk at færre bivirkningsmeldinger skal føre til mer kunnskap om bivirkninger. Det europeiske legemiddelverket (EMA) mottar omtrent 3000 bivirkningsmeldinger hver dag, og omtrent 2000 potensielle signaler på mulige bivirkninger utredes hvert år av EMA (2). Genereringen av disse potensielle signalene påvirkes ikke av rapporteringen for noen andre bivirkninger enn akkurat den bivirkningen som er i signalet. Hvert enkelt signal utredes basert på informasjonen i meldingene som er mottatt samt informasjon fra andre kilder, som den medisinske litteraturen (3). Dermed er ikke støy i form av meldinger om feilbruk en faktor som betyr noe for muligheten til å oppdage nye bivirkninger, verken statistisk eller klinisk.

I 2014 var det faktisk et signal fra bivirkningsmeldinger der feilbruk (medication error) ble oppdaget nettopp fordi det har blitt meldt inn i spontanrapporteringssystemet. Signalet var på legemiddelet Leuprolelin (Procren Depot), og legemiddelet ble gjort tryggere i bruk ved at pasientinformasjonen ble endret og ved at det ble sendt ut informasjon til forskrivere og apotek (2).

Jeg er ikke helt sikker på hva Slørdal og medarbeidere er redd for at kan skje. Er faren at systemene som i dag behandler bivirkningsmeldinger skal bli overbelastet? Dette er neppe et problem, da de allerede $\mathrm{i}$ dag håndterer svært store mengder data daglig. Eller er faren at legene skal sende inn så mange meldinger om feilbruk at de glemmer å melde fra om andre bivirkninger? All den tid de omtrent 28000 legene i Norge (4) sender inn omtrent 1700 meldinger per år (5), eller 0,6 meldinger per lege per år, så virker dette noe usannsynlig.

Om det er riktig å kalle disse meldingene om feilbruk for bivirkninger, er nå én ting, det er uansett viktig å melde om konsekvenser ved feilbruk nettopp for å kunne ta tak i dette og gjøre legemidler tryggere i bruk.

\section{Kristian Svendsen}

kristian.svendsen@uit.no

Kristian Svendsen (f. 1982) er postdoktor ved Sykehusapoteket i Troms $\varnothing$ Oppgitte interessekonflikter: Svendsen har tidligere vært ansatt ved European Medicines Agency (2012-2014) og hvor han jobbet med bivirkningsrapporter og generering av Electronic Reaction Monitoring Reports, et statistisk verktøy i signaldetektering ved EMA.

\section{Litteratur}

1. Slørdal L, Christoffersen T. Et ulogisk og uheldig bivirkningsbegrep. Tidsskr Nor Legeforen. Publisert først på nett 12. oktober 2015. doi: 10.4045/tidsskr.15.0973

2. European Medicines Agency. 2014 Annual Report on EudraVigilance for the European Parliament, the Council and the Commission. 2015 www.ema.europa.eu/docs/en GB/document_library/Report/2015/05/ WC500186342.pdf (12.10.2015)

3. European Medicines Agency. 2013. Standard operating procedure. Signal management for centrally authorised products. www.ema.europa.eu/docs/en_GB/ document_library/Standard_Operating_Procedure_-_SOP/2009/09/ WC500002962.pdf (26.10.2015).

4. Den norske legeforening. Legestatistikk. http://legeforeningen.no/Emner/ Andre-emner/Legestatistikk/ (12.10.2015)
5. Seksjon for legemiddelovervåking ved statens legemiddelverk. Bivirkningsrap port 2013. http://www.legemiddelverket.no/Nyheter/Bivirkninger/Lists/ PageAttachments/Bivirkningsrapport-for-2013-\%E2\%80\%93-hva-kan-vi-l\%C3 \%A6re/NO/Bivirkningsrapport\%202013.pdf (26.10.2015).

\section{Slørdal og T. Christoffersen svarer:}

Kristian Svendsen tillegger oss meninger vi ikke har gitt uttrykk for. Vi er ikke bekymret for at systemene skal overbelastes, tvert i mot mener vi det er et stort problem at norske leger i så stor grad unnlater å melde inn reelle bivirkninger. Hovedlinjen i Svendsens argumenter, nemlig at systemene uansett fanger opp «akkurat den bivirkningen som er i signalet», er vanskelig å følge, spesielt når de innmeldte bivirkningene varierer mellom å være egentlige bivirkninger og alle slags følger av misbruk, overdoser, feilbruk, bruk utenfor godkjent bruksområde og yrkeseksponering (1).

Vårt anliggende er ikke systemene. Vi er bekymret over legemiddelbivirkninger som klinisk problem, og mener at alle, og særlig pasientene, er tjent med at et så sentralt diagnostisk begrep har faglig forankring og høyt presisjonsnivå. Hovedpoenget vårt er at vi må opprettholde en klar, entydig forståelse av hva bivirkninger er. Det er viktig på mange måter, for legen som skal informere pasienten om muligheten for bivirkninger ved en behandling, for all meningsfull faglig diskusjon av problemet og for forskning som forsøker å finne årsakssammenhenger og forbedre terapien.

\section{Lars Slørdal}

lars.slordal@ntnu.no

Thoralf Christoffersen

Lars Slørdal (f. 1955) er professor i farmakologi og overlege i klinisk farmakologi ved Norges teknisk-naturvitenskapelige universitet/St. Olavs hospital.

Ingen oppgitte interessekonflikter.

Thoralf Christoffersen (f. 1941) er professor emeritus ved Avdeling for farmakologi, Institutt for klinisk medisin, Universitetet i Oslo.

Ingen oppgitte interessekonflikter.

Litteratur

1. Bivirkningsrapport 2013, Oslo: Seksjon for legemiddelovervåkning. Statens legemiddelverk, 2013: 17. www.legemiddelverket.no/Nyheter/Bivirkninger/ Lists/PageAttachments/Bivirkningsrapport-for-2013-\%E2\%80\%93-hva-kanvi-1\%C3\%A6re/NO/Bivirkningsrapport\%202013.pdf (8.7.2015).

\section{Re: En kvinne i 70-årene med dekompensert hjertesvikt under operasjon}

Takk for en interessant artikkel som illustrerer inhalert NOs kraftige vasodilatasjonseffekt på lungearteriene (1). Kasuistikken illustrerer at pulmonal hypertensjon kan by på hemodynamiske utfordringer. Det er nylig utgitt nye europeiske retningslinjer for pulmonal hypertensjon (2).

Pulmonal hypertensjon skyldes hyppigst venstresidig hjertesykdom, lungesykdom er også vanlig årsak, noe sjeldnere er årsaken kronisk tromboemboli eller sykdom i lungearteriene primært (pulmonal arteriell hypertensjon) (2). I den preoperative kardiologiske vurderingen kommer det ikke klart frem om man har flere forklaringer på pasientens pulmonale hypertensjon. Pasienten hadde gjennomgått et hjerteinfarkt tidligere, men hadde nå en hyperdynamisk venstre ventrikkel og en trykkbelastet høyre ventrikkel. Det er for oss uklart om pasientens høyresidige hypertrofi og pulmonale hypertensjon forklares av venstresidig hjertesykdom (diastolisk dysfunksjon?) og om utfyllende utredning med tanke på alternative årsaker var utført. Slik utredning mener vi kunne vært aktuelt, inkludert utredning med lungefunksjonstester, lungescintigrafi/ CT-lungearterier og høyresidig hjertekateterisering. 
Anestesiologisk håndtering ved ren postkapillær pulmonal hypertensjon (venstresidig hjertesykdom) er forskjellig fra prekapillær pulmonal hypertensjon (øvrige grupper). Vasodilatasjon i systemisk sirkulasjon (milrinone, nitroprussid) er risikabelt ved ren prekapillær pulmonal hypertensjon, men gunstig dersom korrekt dosert ved venstresidig hjertesykdom. Motsatt vil ren pulmonal vasodilatasjon (inhalert NO med flere) være gunstig ved pulmonal arteriell hypertensjon, men risikabelt ved ren postkapillær $\mathrm{PH}$, da blod lettere returnerer gjennom lungekretsløpet ved vasodilatert pulmonalarterie. Man bør derfor være sikker på at pasienter ikke har postkapillær pulmonal hypertensjon før man gir inhalert NO. God effekt av inhalert NO kan indikere at pasienten har en dominerende prekapillær komponent som årsak til sin pulmonale hypertensjon. Inhalert NO anbefales brukt som ledd i utredning ved visse typer pulmonal arteriell hypertensjon, men frarådes i nye retningslinjer (2) ved venstresidig hjertesykdom.

\section{Torvald Espeland}

torvald.espeland@gmail.com

Marcel Moufack

Torvald Espeland (f. 1981) er lege i spesialisering i indremedisin ved lungeavdelingen på St. Olavs Hospital.

Ingen oppgitte interessekonflikter.

Marcel Moufack (f. 1967) er spesialist i hjertesykdommer og overlege ved klinikk for hjertemedisin, St. Olavs Hospital.

Ingen oppgitte interessekonflikter.

Litteratur

. Brede JR. En kvinne i 70-årene med dekompensert hjertesvikt under operasjon. Tidsskr Nor Legeforen 2015; 135: 1366-8

2. Galiè N, Humbert M, Vachiery J-L et al; Authors/Task Force Members; Authors/ Task Force Members. 2015 ESC/ERS Guidelines for the diagnosis and treatment of pulmonary hypertension: The Joint Task Force for the Diagnosis and Treatment of Pulmonary Hypertension of the European Society of Cardiology (ESC) and the European Respiratory Society (ERS)Endorsed by: Association for European Paediatric and Congenital Cardiology (AEPC), International Society for Heart and Lung Transplantation (ISHLT). Eur Heart J 2015; ehv317. [Epub ahead of print].

\section{Re: En tvillinggravid kvinne med polyuri og polydipsi}

Takk for en spennende diagnosejakt i denne interessante artikkelen om akutt fettlever i svangerskapet (1). I artikkelen er det imidlertid en misforståelse der forfatteren skriver: «Med tanke på pasientens store vannlatingsvolum ble det foreslått redusert utskilling av antidiuretisk hormon (SIADH) og diabetes insipidus som årsak til polyuri. Med u-osmolalitet på $88 \mathrm{mosmol} / \mathrm{kg}(300-900)$ og med s-elektrolytter og osmolalitet i normalområdet var SIADH usannsynlig diagnose.» Det er en misforståelse at SIADH skyldes redusert ADH. «I»en i SIADH står for «inappropriate», og betyr for mye $\mathrm{ADH}$, og derfor vanligvis mindre vannlating (2).

\section{Erik Waage Nielsen}

erikwn@me.com

Erik Waage Nielsen (f. 1956) er anestesilege ved Nordlandssykehuset, Bodø.

Ingen oppgitte interessekonflikter.

\footnotetext{
Litteratur

1. Tandberg AN. En tvillinggravid kvinne med polyuri og polydipsi. Tidsskr Nor Legeforen 2015; 135: 1561-3.

2. Gjerstad L. SIADH-syndrom. Store medisinske leksikon. https://sml.snl.no/ SIADH-syndrom (29.9.2015).
}

\section{Re: Livsstilsmisjonæren}

Berit Nordstrand er intervjuet i Tidsskriftet nr. 18/2015 (1). Hun gir helhetlige, gode kostråd, og hun promoterer en kost med mye plantemat og fullkorn. Dette er bra. Men jeg er uenig i at man skal hente mer pensum fra ernæringsterapeuter, som blant annet læren om at vi ikke er evolusjonstilpasset moderne landbruksprodukter, inn i ernæringsfysiologens utdanning. Meg bekjent neglisjerer ernæringsterapeuter ofte fullkorn på bakgrunn av at vi ikke er tilpasset dette. At vi er 99,995 \% genetisk like våre forfedre behøver ikke å bety så mye, det er genomet som er av betydning. Mutasjon i laktase er et eksempel. Hva som defineres som mat for mennesker, beror på den kjemiske sammensetning og matens mikrobielle trygghet, ikke hva vi spiste før i tiden.

Hvor mye vet vi egentlig om kostholdet via evolusjonen? Evolusjon har foregått over utrolig lang tid i ulike befolkninger, som igjen hadde forskjellige forutsetninger. Jeg mener det er en feilslutning å tro at vi mennesker har vært tilpasset et spesifikt miljø eller en selektiv kost. Nordstrand har selv postulert og lagt fram påstander som går mot grunnleggende agronomi. Et eksempel er påstander om at kunstgjødsel er en årsak til å gi «forringet ernæringsmessig kvalitet» (2) og at urkorn er sunnere enn moderne sorter, noe litteraturen ikke gir støtte til (3). Både natur- og kunstgjødsel trengs for plantevekst. Økt vekst gir økt organisk materiale med høyere mikrobiologisk aktivitet som resultat. Dette er ikke begrenset til en selektiv driftsform. Det er typen frøsort som er mest potent til å gi variasjoner, deretter andre miljøfaktorer som jordsmonn, eventuell bruk av plantevernmidler og type gjødsel (4). Samlet finner man ikke signifikante forskjeller mellom driftsformer, som senest oppsummert av Vitenskapskomitéen for Mattrygghet i fjor (5). Det er snedig å snakke om korns ernæringskvalitet uten å nevne HEALTHGRAIN-prosjektet, som kvantifiserte innholdet av flere forskjellige frøsorter i den hensikt å forstå hvilke komponenter i fullkorn som ser ut til å gi positive helseeffekter (6).

Berit Nordstrand kan ikke hevde å besitte en fasit for hva mennesker skal spise begrunnet ut fra evolusjon, og jeg synes hun utviser dårlig forståelse når det gjelder pensum i ernæringsstudier. Nordstrand har nylig blitt kritisert av ernæringsmiljøet for flere av sine påstander (7).

\section{Daniel Bieniek}

dukiesan@gmail.com

Daniel Bieniek (f. 1985) er masterstudent i samfunnsernæring ved Høyskolen i Oslo og Akershus.

Ingen oppgitte interessekonflikter.

\section{Litteratur}

1. Reymert J. Livsstilsmisjonæren. Tidsskr Nor Legeforen 2015; 135: 1638-40.

2. Nordstrand B. Hvorfor grove korn? http://beritnordstrand.no/hvorfor-grovkorn/ (9.10.2015).

3. Shewry PR, Heya S. Do «ancient» wheat species differ from modern bread wheat in their contents of bioactive components? J Cereal Sci 2015; 65: 236-43.

4. Shewry PR, Hawkesford MJ, Piironen V et al. Natural variation in grain composition of wheat and related cereals. J Agric Food Chem 2013; 61: 8295-303.

5. Vitenskapskomiteen for Mattrygghet. Sammenligning av økologisk og konvensjonell mat og matproduksjon. 30.4.2014. http://vkm.no/eway/ default.aspx?pid=277\&trg=Content_6500\&Main_6177=6500:0:31,2296\&Content_ 6500=6187:2070363:0:6712:1:0:0 (9.10.2015)

6. van der Kamp JW. THE HEALTHGRAIN PROJECT and whole grain products. http://wholegrainscouncil.org/files/EUHealthGrainvanderKamp.pdf (9.10.2015)

7. Bjørnstad S, Holm AH. Ernæringseksperter reagerer på kostholdutsagn: - Jeg trodde Nordstrand var lege, hvordan kan hun stå inne for slike păstander? Side 2, 24.7.2015. www.side2.no/helse/ernringseksperter-reagerer-pakostholdutsagn---jeg-trodde-nordstrand-var-lege-hvordan-kan-hun-sta-innefor-slike-pastander/3422812184.html (9.10.2015). 